\title{
DENTAL STUDENTS' PERCEPTIONS OF DISTANCE LEARNING IN TERMS OF VARIOUS VARIABLES DURING A TRANSITION DUE TO COVID-19
}

\author{
Duygu Recen ${ }^{1}$, Aysel Başer ${ }^{2}$, Bengisu Yldırım ${ }^{3}$ \\ 'Department of Restorative Dentistry, Faculty of Dentistry, Izmir Democracy University, Turkey \\ ${ }^{2}$ Department of Medical Education, Faculty of Medicine, Izmir Democracy University, Turkey \\ ${ }^{3}$ Department of Prostodontics, Faculty of Dentistry, Usak University, Turkey
}

\begin{abstract}
INTRODUCTION: Coronavirus disease was declared as pandemic on February 11, 2020, with high mortality rates. It has caused public health concerns and affected social lifestyle of people, healthcare systems, and educational system.

ОвјестіVEs: The aim of this cross-sectional study was to investigate students' perceptions of distance learning in pre-clinic (first- and second-year) classes.

MATERIAL AND METHODs: This study was conducted during the spring of 2020 on 125 pre-clinic dental students using a web-based questionnaire, with 40 close-ended and two open-ended questions developed based on existing literature about distance learning. Responses were analyzed using Kolmogorov-Smirnov test, independent $t$-test, $\chi^{2}$ test, and Mann-Whitney $U$ test.

RESULTs: No significant differences were observed among all the scales $(p>0.05)$. However, when the scales were evaluated according to gender and grade, the preference scale showed statistically significant difference in gen$\operatorname{der}(p=0.029)$. Most of the students $(47.9 \%$ strongly agree and $60.9 \%$ agree $)$ thought that distance learning was a supportive factor for traditional teaching methods. Quantitative analyses revealed that although many students perceived the positive features of distance learning, including accessibility and flexible time management, some suffered from inequality in accessing the Internet.

ConcLusions: These findings suggest that even though distance learning is a valuable and preferable method for theoretical lessons, it can only be a supportive factor for formal education, as dental clinic skill lessons require faceto-face education. Dental schools should consider an alternate plan with appropriate policies for future pandemics.
\end{abstract}

KEY wORDs: distance learning, face-to-face, learning, dental students, COVID-19.

J Stoma 2021; 74, 2: 116-123

DOI: https://doi.org/10.5114/jos.2021.106498

\section{INTRODUCTION}

Coronavirus disease 2019 (COVID-19) was firstly recorded in Wuhan, China, and was subsequently declared a pandemic by the World Health Organization (WHO) on February 11, 2020, with high mortality rates [1]. The disease has affected social lifestyle of people, healthcare systems, and global economy. Based on the aerosolgenerating procedures in dentistry, the Occupational Safety and Health Administration (OSHA.gov) classi-

\section{JOURNAL OF} STOMATOLOGY CZASOPISMO STOMATOLOGICZNE 
fied dentists as a very high-risk category [2]. Further, on March 16, 2020, the ADA (American Dental Association) advised dental professionals to restrict treatments to emergency cases [3]. Social distance between individuals has been recommended to avoid infection [4]. Many dental schools in Turkey were partially or totally locked down as in other countries, to minimize large gatherings of students in a room [4]. Therefore, to protect students, educators, and patients, and ensure the continuity of education, most dental schools transferred their educational program to distance learning [2].

Dental education is mainly composed of three parts: lecture, simulation laboratory courses, and clinical skill training. Although lectures are easily transferred to distance learning format, pre-clinical courses require practice with simulation models, and need to be controlled by the educators. Current facilities do not sufficiently provide digital or virtual reality techniques in most universities; thus, close contact between the educator and the students during pre-clinicals are unavoidable. Clinical skill training poses even more difficulty during the pandemic given the close contacts among the intern, educator, and patient. As such, many universities have suspended clinics except for emergencies [4].

In this dynamic situation, educators need to work harder to keep students motivated and engaged in distance learning. The exigency of the pandemic allowed no time for educators to learn how to teach online synchronously or asynchronously. Synchronous teaching is useful in promoting peer interactions and critical thinking skills in distance learning, whereas asynchronous teaching involves independent learning, which even experienced educators can find it challenging to keep students engaged and motivated. Blended learning includes both synchronous and asynchronous teaching methods [2].

Distance learning is defined as an education form that separates the students physically from the educators. This learning format should be well designed, interactive, and student-centered to better achieve learning goals individually or in groups. Moreover, distance learning saves time, reduces expenses, and allows students to access education at any time and place of their choosing $[5,6]$.

Distance learning requires a different format than traditional education. Its success depends both on the experience and attitudes of students towards technology and the teaching skills of the educator. It is important to maximize student's satisfaction, as their perception is crucial in evaluating any distance learning program. Moreover, educators have to learn faster given the rapid evolution of technology and information [7]. Furthermore, it is important for students to understand the requirements of computer technologies to fully obtain a decent distance learning. As such, universities have a big role in training and equipping both the students and the educators for this new environment of learning and teaching using continuing education centers [8]. Therefore, each university should take into consideration changes in training program that can be successfully implemented during this time [2].

Coronaviruses have already caused two outbreaks - severe acute respiratory syndrome (SARS) and Middle East respiratory syndrome (MERS) - since 2002. Although there are articles about SARS [9] and MERS [10], their effects on medical education, limited studies on COVID-19, and its relationship with distance learning in undergraduate dentistry students were published [11-14]. Moreover, to the authors' knowledge, there have been only a few studies $[13,14]$ conducted in Turkey so far. Therefore, to address this gap in the literature, this study aimed to analyze and describe the experience of dental students enrolled in a blended (synchronous and asynchronous) distance learning dental program. Perceptions of blended distance learning in pre-clinic (first and second) classes during this change in dental education may provide an opportunity to evaluate the limitations of blended distance learning programs at university level. The findings of this study may be helpful when remodeling dental curriculum during this era and in future emerging pandemic diseases.

\section{OBJECTIVES}

The first null hypothesis of the study was that the efficiency scale, audio and video quality scale, ease of use scale, communication scale, technical support scale, preference scale, and educator development scale of blended distance learning would not change with regards to gender or grade. The second null hypothesis was that students would not find any difference between the satisfaction of blended distance learning and that of face-to-face education. The third null hypothesis was that distance learning would be replaced to all face-to-face educations, including clinic skill and theoretical lessons. The fourth null hypothesis was that students would perceive communication with the educators as sufficient.

\section{MATERIAL AND METHODS}

This mixed method (quantitative and qualitative) research was conducted on dental students of the Faculty of Dentistry, İzmir Democracy University, Turkey in October 2020. The study was carried out according to the Helsinki Declaration, and ethical permission was obtained from the local ethics committee of İzmir Democracy University (date, September 29, 2020; number, 2020/20-1).

The distance learning at the İzmir Democracy University Faculty of Dentistry was developed in the spring semester of 2020 by using the cloud app digital hub program, Microsoft Teams (version 6). Lecture contents were adapted to an online format prior to synchronous distance learning program. The program provided recorded audio lectures for students at their own availabil- 
ity for asynchronous learning. Theoretical lessons were held for 9 weeks of 10 lessons per week for first grade students, and 17 lessons per week for second grade students.

\section{QUESTIONNAIRE}

Perceptions of blended distance learning was assessed by a web-based questionnaire (WBQ), developed by the researchers with the help of literature $[5,11,15]$. The WBQ was examined and determined as appropriate by two-field experts, a public health expert and a medical educator. The data was collected by sending an online link via student WhatsApp groups to each student and the results were collected through Google Forms (https://docs.google.com/forms/d/e/1FAIpQLSfdJMDt4QWZxI-RolEWm8SU_wOx4kdqDxF37aiKnnpHhC2KEQ/viewform?usp=sf_link).

The students were informed that participation in the study was voluntary, and this information was provided at WBQ. Students were suitable for the research if they were willing to complete the WBQ and were able to answer the questions in Turkish. The WBQ was administered to first and second grade dental students, as they were in the pre-clinic stage of their education. All the students were participating in the distance learning program, and 125 out of 139 students volunteered to complete the WBQ. Therefore, all 125 students both in the first class $(n=73)$ and the second class $(n=51)$ were participated in the study. One of the students did not provide an answer to the question regarding the grade.

In the first part of the WBQ, there were "socio-demographic questions" to determine the students' gender, age, class, and their previous participation in any distance education program. The second part consisted of "satisfaction survey for distance learning" questions, which included 40 closed-ended questions. The participants were asked to choose an answer as "strongly disagree", "disagree", "neutral", "agree", or "strongly agree" to each question in the form of a five-point Likert scale. The questions in the second part could be categorized as a 14-item efficiency scale (A), a 3-item audio and video quality scale (B), an 8-item ease of use scale (C), a 5-item communication scale (D), a 5-item technical support scale (E), a 3-item preference scale $(\mathrm{F})$, and a 2-item educator development scale $(\mathrm{G})$.

In the third part of the WBQ, two open-end questions were asked for the qualitative data analysis: (1) Briefly write the contributions of the distance education portal to your education and a three aspects you find positive, and (2) Briefly describe the aspects of the distance education portal that need to be improved and a three aspects you find negative. Written opinions of the students were independently examined by three researchers and codes were created. Subsequently, the research worked as a team to generate main themes from the responses. The themes were compared and combined as necessary $[16,17]$.

\section{STATISTICAL ANALYSIS}

The sample size was calculated using Raosoft sample size calculator, and a margin of error set at 4.5\% in 95\% confidence interval was found to be at least in 106 participants. Statistical analyses were performed using SPSS software (version 22, IBM Corporation, Armonk, NY, USA), and the statistical significance level was set at 0.05. Mixed methods of data analysis were applied depending on characteristics of the data collection tool used in this research. Percentages were used to describe the socio-demographic data of the students in quantitative data analysis. The frequency, percentage, and arithmetic mean distributions of the responses provided to each of the options were used to determine the level of student's view on the synchronous and asynchronous implementation of distance learning. Kolmogorov-Smirnov test was used for distribution statistics, independent $t$-test for normal distributions, and Mann-Whitney $U$ test for non-normal distributions. Data analysis was performed with chi-square for categorical variables.

\section{RESULTS}

Of the 139 students contacted, 125 students completed the questionnaire. This represents a response rate of $89.9 \%$. The study sample consisted of 73 first grade and 51 second grade dental students. One of the students did not answer the grade question.

Based on their demographics, students indicated the use of smartphones, computers, or both smartphones and computers as the choices of device for their distance education. No significant difference was found between the satisfaction of the audio and visual support of the devices $(p=0.171)$ and the ease of use $(p=0.754)$ in distance education.

Further, the results showed no statistically significant difference between the efficiency scale, video quality scale, ease of use scale, communication scale, technical support scale, preference scale, and educator development scale as parts of the questionnaire, without significant effects on gender or grade $(p>0.05)$.

When the efficiency scale, video quality scale, ease of use scale, communication scale, technical support scale, preference scale, and educator development scale were evaluated according to gender and grade, only the preference scale showed a statistically significant difference based on gender $(p=0.029)$; no statistically significant difference was observed in grade among these scales $(p=0.377)$.

Higher percentage of the data collected from the efficiency scale, video quality scale, ease of use scale, communication scale, technical support scale, preference scale, and educator development scale are presented in Table 1.

As a result of the qualitative data analysis, 16 positive codes were created. These codes were categorized into 
TABLE 1. Higher percentage of the data collected from the scales used

\begin{tabular}{|c|c|c|c|c|c|c|}
\hline & Strongly disagree & Disagree & Neutral & Agree & Strongly agree & Total \\
\hline \multicolumn{7}{|l|}{ Efficiency scale } \\
\hline \multicolumn{7}{|c|}{ Distance education is effective in line with the objectives and learning objectives of the courses } \\
\hline Male (\%) & 6.6 & 22.4 & 35.5 & 26.3 & 9.2 & 100 \\
\hline Female (\%) & 10.0 & 28.6 & 22.4 & 22.4 & 16.3 & 100 \\
\hline First grade (\%) & 8.2 & 17.8 & 32.9 & 28.8 & 12.3 & 100 \\
\hline Second grade (\%) & 7.8 & 35.3 & 27.5 & 17.6 & 11.8 & 100 \\
\hline \multicolumn{7}{|c|}{ I know that I can access and use the records of live lessons that I could not attended in the distance education portal } \\
\hline Male (\%) & 5.3 & 5.3 & 2.6 & 26.3 & 60.5 & 100 \\
\hline Female (\%) & 0.0 & 6.1 & 2.0 & 10.2 & 81.6 & 100 \\
\hline First grade (\%) & 2.7 & 4.1 & 4.1 & 24.7 & 64.4 & 100 \\
\hline Second grade (\%) & 3.9 & 7.8 & 0.0 & 11.8 & 76.5 & 100 \\
\hline \multicolumn{7}{|c|}{ I think that live lessons are equivalent to face-to-face education on the distance education portal } \\
\hline Male (\%) & 36.8 & 30.3 & 15.8 & 9.2 & 7.9 & 100 \\
\hline Female (\%) & 34.7 & 26.5 & 20.4 & 12.2 & 6.1 & 100 \\
\hline First grade (\%) & 35.6 & 24.7 & 20.5 & 12.3 & 6.8 & 100 \\
\hline Second grade (\%) & 37.3 & 33.3 & 13.7 & 7.8 & 7.8 & 100 \\
\hline \multicolumn{7}{|c|}{ I think the distance education portal is a supportive factor for formal education } \\
\hline Male (\%) & 7.9 & 19.7 & 28.9 & 30.3 & 13.2 & 100 \\
\hline Female (\%) & 2.0 & 14.3 & 18.4 & 30.6 & 34.7 & 100 \\
\hline First grade (\%) & 9.6 & 8.2 & 28.8 & 32.9 & 20.5 & 100 \\
\hline Second grade (\%) & 0.0 & 29.4 & 19.6 & 27.5 & 23.5 & 100 \\
\hline \multicolumn{7}{|l|}{ Video quality scale } \\
\hline \multicolumn{7}{|c|}{ I think it facilitates my learning due to the audio and visual support of the distance education portal } \\
\hline Male (\%) & 10.5 & 21.1 & 35.5 & 21.1 & 11.8 & 100 \\
\hline Female (\%) & 12.2 & 16.3 & 30.6 & 28.6 & 12.2 & 100 \\
\hline First grade (\%) & 6.8 & 16.4 & 37.0 & 26.0 & 13.7 & 100 \\
\hline Second grade (\%) & 17.6 & 21.6 & 29.4 & 21.6 & 9.8 & 100 \\
\hline \multicolumn{7}{|l|}{ Ease of use scale } \\
\hline \multicolumn{7}{|c|}{ Instructions for using the distance education portal were clear } \\
\hline Male (\%) & 4.0 & 9.3 & 17.3 & 34.7 & 34.7 & 100 \\
\hline Female (\%) & 0.0 & 6.1 & 10.2 & 32.7 & 51.0 & 100 \\
\hline First grade (\%) & 4.2 & 8.3 & 19.4 & 36.1 & 31.9 & 100 \\
\hline Second grade (\%) & 0.0 & 7.8 & 7.8 & 31.4 & 52.9 & 100 \\
\hline \multicolumn{7}{|c|}{ I can access the course contents of distance education quickly } \\
\hline Male (\%) & 1.3 & 6.6 & 13.2 & 44.7 & 34.2 & 100 \\
\hline Female (\%) & 0.0 & 2.0 & 20.4 & 26.5 & 51.0 & 100 \\
\hline First grade (\%) & 1.4 & 4.1 & 17.8 & 38.4 & 38.4 & 100 \\
\hline Second grade (\%) & 0.0 & 5.9 & 13.7 & 37.3 & 43.1 & 100 \\
\hline \multicolumn{7}{|l|}{ Communication scale } \\
\hline \multicolumn{7}{|c|}{ I can easily convey my questions, ideas, and troubles related to the distance education system and courses to faculty members } \\
\hline Male (\%) & 3.9 & 17.1 & 14.5 & 28.9 & 35.5 & 100 \\
\hline Female (\%) & 4.1 & 14.3 & 22.4 & 30.6 & 28.6 & 100 \\
\hline First grade (\%) & 15.1 & 34.2 & 20.5 & 19.2 & 11.0 & 100 \\
\hline Second grade (\%) & 17.6 & 33.3 & 27.5 & 15.7 & 5.9 & 100 \\
\hline
\end{tabular}


TABLE 1. Cont.

$\begin{array}{llllll}\text { Strongly disagree } & \text { Disagree } & \text { Neutral } & \text { Agree } & \text { Strongly agree } & \text { Total }\end{array}$

Technical support scale

I know how to solve problems that may encounter during the registration period on the e-learning portal

\begin{tabular}{l|l|l|l|l|l|l}
\hline Male (\%) & 5.3 & 13.2 & 25.0 & 27.6 & 28.9 & 100 \\
\hline Female (\%) & 6.1 & 10.2 & 28.6 & 28.6 & 26.5 & 100 \\
\hline First grade (\%) & 6.8 & 8.2 & 27.4 & 24.7 & 32.9 & 100 \\
\hline Second grade (\%) & 3.9 & 15.7 & 25.5 & 33.3 & 21.6 & 100 \\
\hline
\end{tabular}

Preference scale

Thanks to distance education, I can save my time and deal with my other interests

\begin{tabular}{|l|c|c|c|c|c|c|}
\hline Male (\%) & 9.2 & 19.7 & 17.1 & 18.4 & 35.5 & 100 \\
\hline Female (\%) & 8.2 & 8.2 & 10.2 & 26.5 & 46.9 & 100 \\
\hline First grade (\%) & 5.5 & 16.4 & 15.1 & 21.9 & 41.1 & 100 \\
\hline Second grade (\%) & 13.7 & 13.7 & 13.7 & 21.6 & 37.3 & 100 \\
\hline
\end{tabular}

Educator development scale

Educators need further development for the distance learning portal to support my learning

\begin{tabular}{l|c|c|c|c|c|c|}
\hline Male (\%) & 4.1 & 9.5 & 27.0 & 36.5 & 23.0 & 100 \\
\hline Female (\%) & 2.0 & 12.2 & 22.4 & 32.7 & 30.6 & 100 \\
\hline First grade (\%) & 2.8 & 9.9 & 29.6 & 32.4 & 25.4 & 100 \\
\hline Second grade (\%) & 3.9 & 11.8 & 19.6 & 39.2 & 25.5 & 100 \\
\hline
\end{tabular}

TABLE 2. Positive questions to open-ended questions

\begin{tabular}{|l|l|l|}
\hline Sub-themes & Categories $(\boldsymbol{n}=\mathbf{1 6})$ & Quotations \\
\hline Ease of use & $\begin{array}{l}\text { Fast, accessible, repetitive, practical use, easy, } \\
\text { freedom, comfort }\end{array}$ & $\begin{array}{l}\text { "I have unlimited access to lecture notes and video content" } \\
\text { "I can repeat the lessons I missed" }\end{array}$ \\
\hline Efficiency & $\begin{array}{l}\text { Detailed information, supportive education, } \\
\text { efficiency }\end{array}$ & $\begin{array}{l}\text { "Faster and detailed lessons were given" } \\
\text { "Whenever I want, I can stop, take notes, and continue" }\end{array}$ \\
\hline Sound and image quality & Sound quality, image quality & "Learning is easier with both slides and video explanations" \\
\hline Communication & $\begin{array}{l}\text { Interactive, interaction, educator-student } \\
\text { communication }\end{array}$ & $\begin{array}{l}\text { "Educators are making the lesson more active by asking questions" } \\
\text { "We can communicate more often and easily with educators" }\end{array}$ \\
\hline Preference & $\begin{array}{l}\text { Time management } \\
\text { "Online learning saves time" } \\
\text { "Thanks to the fact that I don't have to go to university and come back, } \\
\text { Ihave 3 hours of time per day" } \\
\text { "I can spare time for different activities" }\end{array}$ \\
\hline
\end{tabular}

five themes (Table 2). Nineteen negative codes were removed and eight themes were named (Table 3).

\section{DISCUSSION}

With the development of information technology, educational system has undergone a great change, and dentistry could not remain unaffected $[8,18]$. Advances in technology, 3D graphic models, online videos, and mobile electronic devices (smartphones, tablets) are gradually finding their place in dentistry education [19]. Prior to the pandemic, Asiry et al. [5] analyzed a 14-state- ment questionnaire that included computer skills, internet access, quality of lectures, and students learning choices. Wheeler [15] compared teaching presence, acquired learning, student-educator interaction, and student-student interaction with or without synchronous distance learning using a questionnaire. As distance learning technologies grow, researchers have focused on the design and quality of online courses and programs, and Baldwin et al. has created an online course design checklist for this purpose [7].

Due to the unexpected pandemic, clinics were abandoned and the conventional teaching patterns were suspended. Both dental students and educators are faced 
TABLE 3. Negative questions to open-ended questions

\begin{tabular}{|c|c|c|}
\hline Sub-themes & Categories $(n=19)$ & Quotations \\
\hline Ease of use & Difficult to use & $\begin{array}{l}\text { "The videos on the system are not well arranged, and it is making difficult } \\
\text { to find the desired lesson" }\end{array}$ \\
\hline Efficiency & $\begin{array}{l}\text { Ineffective in practical lessons, supportive } \\
\text { education, focus, ineffective (both clinic skills and } \\
\text { theoretical lessons), passive student's participation }\end{array}$ & $\begin{array}{l}\text { "Online learning certainly cannot replace formal education, but can only } \\
\text { be a temporary alternative" } \\
\text { "Online learning offers passive student participation" } \\
\text { "Online learning is a low memorable method" }\end{array}$ \\
\hline Sound and image quality & Sound quality, image quality & "Sound and image quality deteriorates occasionally" \\
\hline Communication & Educator-student communication & $\begin{array}{l}\text { "Our communication with educators is missing from time to time due to } \\
\text { internet problems" }\end{array}$ \\
\hline Technology & Program software, internet, power failure, device & $\begin{array}{l}\text { "I am having internet connection problems" } \\
\text { "I am having an audio video synchronization problem due to internet } \\
\text { connection problems" } \\
\text { "I am having connection problems when using smartphone" }\end{array}$ \\
\hline Educator development & $\begin{array}{l}\text { Training, instructional presentation technique, } \\
\text { technology handicapped educator }\end{array}$ & "Some educators cannot use the system well enough" \\
\hline Discipline & Inordinance & "I cannot work as disciplined as we go to university" \\
\hline Inequality & Inequality, cost & "I cannot connect to the internet due to power failure problem" \\
\hline
\end{tabular}

with a distance learning platform, which presents a challenge especially for teaching clinical skills [11]. Although their curricula have not been fully transformed, many researchers in dental schools support distance learning programs [5, 20-22].

In Turkey, there has been no distance learning programs for undergraduate dental students before the pandemic, and universities were caught unprepared by the COVID-19 pandemic. Therefore, educators shifted to emergency remote teaching to keep their educators, staff, students, and patients safe [23]. Further, there is lack of literature about comparative effects of the novel COVID-19 and on undergraduate dental education in distance versus face-to face learning. Thus, in this study, a WBQ was created to study the perception and experiences of dentistry students undergoing distance learning in Turkey.

Cronbach's $\alpha$ establishes reliability of questionnaire by indicating internal consistency. Although acceptable values of Cronbach's $\alpha$ range between 0.70 to 0.95 , a maximum value has been reported as 0.90 [24]. In this study, we achieved highly reliable Cronbach's $\alpha$ coefficients calculated from the responses to the questionnaires ( $n=125, \alpha=0.900)$, and we plan to convert this value to a scale in future studies.

The first null hypothesis of this study was partly accepted given that the preference scale showed statistically significant difference with regards to gender ( $p=0.029$ ). Here, blended distance learning seemed to be a more preferred option for female students. Similar to this study, Al-Taweel et al. [1] revealed that female students presented more favorable attitude than males towards distance learning. Unlike the present study, Mather et al. reported that male students (80\%) preferred online learning more than female students (70\%) [18]. These contradictory results may be related to different sample sizes or evaluation methods.

The second null hypothesis was rejected, since most of the students (36\% strongly disagree and $28.8 \%$ disagree) did not think that "live lessons on distance education are equivalent to face-to-face education". In contrast, only $7.2 \%$ of the students considered that they are equivalent. This is in line with the findings of Asiry et al. [5] who observed a fewer number of students (11.1\% agree and $3.7 \%$ strongly agree) acceded replacing traditional lessons with online learning. Hattar et al. [11] revealed that without statistically significant effect of gender, $67.1 \%$ of the students expressed a preference for online learning. In this study regardless of the gender or grade, the students believed that distance learning did not equate to face-to-face education. This perception may be related to clinical skill lessons and laboratory practices, which need to be physically held by an educator, with phases controlled based on student needs and availability. Karaaslan et al. [14] showed that online learning negatively affected students' education. According to Asiry et al. [5], students' demand for teaching method revealed a preference for a combination of online and face-to-face learning (38.9\% agree and 31.5\% strongly agree). Parallel to this finding, in the present study, although the students' responses to the idea of "distance education is effective in line with the objectives and learning objectives of the courses" (30.4\% neutral, $24.8 \%$ agree, and $12 \%$ strongly agree) were not clear enough, more than half of the students (30.9\% agree and $21.6 \%$ strongly agree) considered "the distance education portal is a supportive factor for formal education". Thus, the third null hypothesis of the study was rejected. 
In contrast, most of the students (19.3\% agree and $69.3 \%$ strongly agree) thought that "I know that I can access and use the records of live lessons that I could not attend in the distance education portal". Gonzalez et al. [25] reported that students changed their learning strategies to a more regular habit with higher levels of engagement. Moreover, most students $(21.6 \%$ agree and $40 \%$ strongly agree) thought that "thanks to distance education, I can save my time and deal with my other interests". In the third part of the WBQ, they indicated that "online learning saves time", "thanks to the fact that I don't have to go to school and come back, I have 3 hours of time per day", and "I can spare time for different activities". These responses indicated that although students may not think that distance education is as good as face-toface learning, they are still satisfied with the outcomes.

The fourth null hypothesis was accepted as more than half of the students (35.5\% male and $28.6 \%$ female) strongly agreed that "I can easily convey my questions, ideas and troubles related to distance education system and courses to faculty members". On the contrary, Abbasi et al. [12] reported that $84 \%$ of students thought that educator-student interaction is limited in online learning. Compared to this result, the finding reflected that the educators had managed the current crisis very well while shifting to the emergency remote teaching. Most of the students (33.6\% agree and $40.8 \%$ strongly agree) thought that "instructions for using the distance education portal were clear". This response supports the good communication between educator and students. However, there was a conflicting in responses to questions regarding educators' professional development, although many of the students (34.4\% agree and $25.6 \%$ strongly agree) thought that educators had no problem using the distance education portal. Exactly the same proportion of the students $(34.4 \%$ agree and $25.6 \%$ strongly agree) were not satisfied and thought that educators needed further development for the distance education. To address this conflicting perceptions with educator development, separate surveys can be designed for each educator and each course. This survey could address the ease of access as lessons needed to be transferred to a different format during the shift to the emergency remote teaching. Gambarini et al. reported that 300 professors in Europe thought that their theoretical lesson classrooms were successfully transferred to distance learning platforms [26].

Moreover, students need to improve their skills in the use of technology. In this study, more than half of the students thought that "the distance education portal seems very complicated to me", although nearly the same number of students agreed that "I can access the course contents of distance education quickly". Consistent with the outcomes of present study, Al-Taweel et al. [1] reported that online learning process was affected by the students' degree of essential computer skills and internet access. Based on our qualitative analysis, the students expressed negative opinions about internet connection, power failure, and smartphone problems. These indicate that students' skills can be improved over time by providing an access to technologies, as disparity in students current conditions appeared to be the biggest problem of online education in Turkey, based on this study.

The limitations of the present study include small sample size and data from only one university. Therefore, the results cannot be generalized. Nevertheless, the findings present information that are valuable, accurate, and representative. Future studies aiming at capturing the perception of online learning programs and experiences of more universities are recommended.

\section{CONCLUSIONS}

The results of this study present distance learning as a valuable and preferable method for theoretical lessons to support formal education, given the requirement of face-to-face lessons in acquiring dental clinical skills. Educators should be willing to consider that emergency remote teaching needs to be improved, and a comprehensive and multidisciplinary approach to dentistry curriculum is needed in cooperation with the departments of educational sciences. The planning of distance education programs should reflect current situations of the students, and efforts should be made to eliminate inequality. Orientation should be planned for the training of educators and students on adapting to distance education. Dental schools should take advantage of COVID-19 pandemic to plan appropriate policies against future epidemics.

\section{CONFLICT OF INTEREST}

The authors declare no potential conflicts of interest with respect to the research, authorship, and/or publication of this article.

\section{References}

1. Al-Taweel FB, Aldulkareem AA, Gul SS, Alshami ML. Evaluation of technology-based learning by dental students during the pandemic outbreak of coronavirus disease 2019. Eur J Dent Educ 2021; 25: 183-190.

2. Iyer P, Aziz K, Ojcius DM. Impact of COVID-19 on dental education in the United States. J Dent Educ 2020; 84: 718-722.

3. American Dental Association. As dental practices resume operations, ADA offers continued guidance. 2020. Available at: https:// www.ada.org/en/press-room/news-releases/2020-archives/may/ as-dental-practices-resume-operations-ada-offers-continuedguidance? [Accessed: October 2020]

4. Chang TY, Hong G, Paganelli C, et al. Innovation of dental education during COVID-19 pandemic. J Dent Sci 2021; 16: 15-20.

5. Asiry MA. Dental students' perceptions of an online learning. Saudi Dent J 2017; 29: 167-170.

6. Grimes EB. Student perceptions of an online dental terminology course. J Dent Educ 2002; 66: 100-107. 
7. Baldwin SJ, Ching YH. An online course design checklist: development and users' perceptions. J Comput High Educ 2019; 31: 156-172.

8. Alshare K, Al-Dwairi M, Akour I. Student-instructor perception of computer technologies in developing countries: the case of Jordan. J Comput Inform Syst 2003; 43: 115-123.

9. Patil NG, Chan Y, Yan H. SARS and its effect on medical education in Hong Kong. Med Educ 2003; 37: 1127-1128.

10. Kharma MY, Alalwani MS, Amer MF, Tarakji B, Aws G. Assessment of the awareness level of dental students toward Middle East Respiratory Syndrome-coronavirus. J Int Soc Prev Community Dent 2015; 5: 163-169.

11. Hattar S, AlHadidi A, Sawair FA, Abd Alraheam I, El-Ma'aita A, et al. Impact of COVID-19 pandemic on dental academia. Students' experience in online education and expectations for a predictable practice. Res Sq 2020; 1: 1-16. doi: 10.21203/rs.3.rs$54480 / \mathrm{v} 1$.

12. Abbasi S, Ayoob T, Malik A, Memon SI. Perceptions of students regarding E-learning during Covid-19 at a private medical college. Pak J Med Sci 2020; 36 (COVID19-S4): S57-S61.

13. Osman A, Yildırım TT. Evaluation of knowledge, attitudes, and clinical education of dental students about COVID-19 pandemic. Peer J 2020; 29: e9575. doi: 10.7717/peerj.9575

14. Karaaslan F, Dikilitaş, Aydın EÖ. Comparison of COVID-19 relevant knowledge and attitudes of clinical and preclinical dental students in Turkey. Balk J Dent Med 2020; 24: 1-7. doi: 10.2478/ bjdm-2020-0021.

15. Wheeler KM. A mixed method study examining synchronousenhanced learning in distance education. Graduate theses and dissertations (2015). Available at: http://scholarcommons.usf.edu/ etd/5865 [Accessed: October 2020].

16. Saban A. Lisansüstü öğrencilerin nitel araştirma metodolojisine ilişkin algilari. SUSBED 2007; 17: 469-485.

17. Fırat M, Yurdakul IK, Ersoy A. Bir eğitim teknolojisi araştırmasına dayalı olarak karma yöntem araştırması deneyimi. JOQRE 2014; 2: 65-86.

18. Mather M, Sarkans A. Student perceptions of online and face-toface learning. IJCI 2018; 10: 61-76.

19. Abdelkarim A, Benghuzzi H, Hamadain E, et al. Dental students' and faculty members' attitudes about technology, instructional strategies, student diversity, and school duration: a comparative study. J Dent Educ 2014; 78: 614-621.

20. Andrews KG, Demps EL. Distance education in the U.S. and Canadian undergraduate dental curriculum. J Dent Educ 2003; 67: 427438.

21. Hendricson WD, Panagakos F, Eisenberg E, et al. Electronic curriculum implementation at North American dental schools. J Dent Educ 2004; 68: 1041-1057.

22. Kassebaum DK, Hendricson WD, Taft T, Haden NK. The dental curriculum at North American dental institutions in 2002-03 a survey of current structure, recent innovations, and planned changes. J Dent Educ 2004; 68: 914-931.

23. Educause review (2020). The Difference Between Emergency Remote Teaching and Online Learning. Available at: https:// er.educause.edu/articles/2020/3/the-difference-between-emergency-remote-teaching-and-online-learning [Accessed: October 2020].

24. Sharma B. A focus on reliability in developmental research through Cronbach's alpha among medical, dental and paramedical professionals A focus on reliability in developmental research through Cronbach's alpha among medical, dental and paramedical professionals. APJHS 2016; 3: 271-278.

25. Gonzalez T, de la Rubia MA, Hincz KP, et al. Influence of COVID-19 confinement in students' performance in higher education. arXiv:2004.09545; 2020. Available at: https://arxiv.org/ abs/2004.09545 [Accessed: October 2020].

26. Gambarini G, Miccoli G, Testarelli L. A survey on the impact of COVID-19 on academic teaching and training in dentistry. Agorà Odontoiatrica 2020 [In press]. 